\title{
EXPERIENCE OF THE INSTITUTE OF ONCOLOGY AND RADIOLOGY OF SERBIA IN RADIOTHERAPY TREATMENT OF MALIGNANT TUMORS IN CHILDREN
}

\section{ISKUSTVO INSTITUTA ZA ONKOLOGIJU I RADIOLOGIJU SRBIJE U RADIOTERAPIJSKOM LEČNJU MALIGNIH TUMORA DECE}

Dragana Stanić1, Jelena Bokun', Marina Nikitovic'1,2

\section{Summary}

The Institute of Oncology and Radiology of Serbia in Belgrade is an institution in which the implementation of radiotherapy of children and adolescents started 35 years ago. To date, pediatric radiotherapy has been set up and has been following technological possibilities and progress, and a highly specialized multidisciplinary team has been established in the institution with a focus on pediatric oncology and radiotherapy. Purchase of equipment for three-dimensional conformal radiotherapy (3D-CRT) in 2006 enabled qualitative progress in the planning and implementation of pediatric radiotherapy.

60 to 80 patients aged 1 to 18 years are treated annually in our institution. For children aged up to 3 years, and in extremely rare cases older, radiotherapy is carried out in anesthesia, which is emphasized as a significant experience and quality of work of our institution. In the ten-year period from January 2007 to September 2016, 648 children were treated with radiotherapy. In the majority of children, 90.6\%, radiotherapy was conducted using 3D conformal technique (3D-CRT) and in small number, $9.4 \%$ with conventional radiotherapy (2D-RT). The most frequent patients were children with central nervous system tumors $30.1 \%$, leukemia $16.5 \%$, bone tumors $15.4 \%$, lymphoma $11.9 \%$, soft tissue sarcoma $11.6 \%$, neuroblastoma $6.5 \%$, nephroblastoma $3.6 \%$, retinoblastoma $1.7 \%$ and other rare tumors. Besides operative treatment, the majority of children were treated with chemotherapy and radiotherapy, $89.8 \%$. Most of the children treated with radiotherapy were treated with chemotherapy in our institution, $45.8 \%$. In a small number of children, radiotherapy was conducted as the only therapeutic approach, $10.2 \%$.

At the Institute for Oncology and Radiology of Serbia, as a central institution for pediatric radiotherapy, 3D-CRT has been fully adopted as a standard in the treatment of children and adolescents. In the past ten years, we have gained our own experiences which will be of great use to us with introduction of advanced techniques that we expect to gain by further purchase of machines and equipment for radiotherapy.

Key words: radiotherapy, pediatric oncology

\section{Sažetak}

Institut za onkologiju i radiologiju Srbije u Beogradu je ustanova u kojoj je pre 35 godina započeto sprovođenje zračne terapije kod dece i omladine. Do danas je osnovana pedijatrijska radioterapija koja se razvijala, pratila tehnološke mogućnosti i napredak, a u ustanovi se formirao visokospecijalizovan multidisciplinarni tim sa usmerenjem ka pedijatrijskoj onkologiji i radioterapiji. Kupovinom opreme za trodimenzionalnu konformalnu radioterapiju (3D-CRT) 2006. godine omogućen je kvalitativni napredak u planiranju i sprovođenju pedijatrijske radioterapije.

Godišnje se zračnom terapijom u našoj ustanovi leči 60 do 80 pacijenata uzrasta od 1 do 18 godina. Za decu uzrasta do 3 godine, izuzetno retko i stariju, zračna terapija se sprovodi u anesteziji što ističemo kao značajno iskustvo i kvalitet rada naše ustanove. U desetogodišnjem periodu od januara 2007. do septembra 2016. godine radioterapijom je lečeno 648 dece. Kod najvećeg broja dece, $90.6 \%$, sprovodena je zračna terapija upotrebom 3D konfomalne tehnike (3D-CRT), a kod malog broja, 9.4\% konvencionalnom radioterapijom (2D-RT). Najčešci pacijenti bili su deca sa tumorima centralnog nervnog sistema $30.1 \%$, leukemijom $16.5 \%$, koštanim tumorima $15.4 \%$, limfomima $11.9 \%$, mekotkivnim sarkomima $11.6 \%$, neuroblastomom $6.5 \%$, nefroblastomom $3.6 \%$, retinoblastomom $1.7 \%$ i ostalim retkim tumorima. Uz operativno lečenje najveći broj dece lečen je hemioterapijom i radioterapijom, $89.8 \%$. Većina dece kod kojih je sprovedena radioterapija lečena je hemioterapijom u našoj ustanovi, 45.8\%. Kod malog broja dece sprovedena je radioterapija kao jedini terapijski pristup, $10.2 \%$.

U Institutu za onkologiju i radiologiju Srbije, kao centralnoj ustanovi za pedijatrijsku radioterapiju, u potpunosti je usvojena 3D-CRT kao standard u lečenju dece i omladine. U proteklom desetogodišnjem periodu stekli smo sopstvena iskustva koja će nam biti od velike koristi prilikom uvođenja naprednijih tehnika koje očekujemo daljom kupovinom uređaja i opreme za radioterapiju.

Ključne reči: radioterapija, pedijatrijska onkologija

\section{UVOD}

Radioterapijski tretman u pedijatrijskoj onkologiji predstavlja veći izazov u odnosu na lečenje odraslih. Velika većina dece se leči kurativnom pristupom za veliki broj maligniteta, od kojih su mnogi ili retki ili ne postoje kod odraslih. Pored toga, tkiva dece imaju manju toleranciju prema zračenju nego tkiva odraslih, a u mnogim slučajevima deca imaju relativno velike ciljne volumene zračenja, koji u zavisnosti od dijagnoze, zahtevaju značajne 
doze (1). Suprotno uobičajenom verovanju, mala deca obično nemaju male tumore. Još jedna razlika u pedijatrijskoj radijacionoj onkologiji je u tome što, za razliku od odraslih, deca često primaju konkomitantnu hemioterapiju. Ovo dodatno smanjuje toleranciju određenih tkiva, na primer, povećava ototoksičnost cisplatine ili toksičnosti antraciklina (2).

Institut za onkologiju i radiologiju Srbije (IORS) u Beogradu je ustanova u kojoj je pre 35 godina započeto sprovođenje zračne terapije kod dece i omladine. Do danas je osnovana pedijatrijska radioterapija koja se razvijala, pratila tehnološke mogućnosti i napredak, a u ustanovi se formirao visokospecijalizovan multidisciplinarni tim sa usmerenjem ka pedijatrijskoj onkologiji i radioterapiji.

Kupovinom opreme za trodimenzionalnu konformalnu radioterapiju (3D-CRT) 2006. godine omogućen je kvalitativni napredak u planiranju i sprovođenju pedijatrijske radioterapije (3). Termin konfomalna radioterapija podrazumeva primenu tehnika zračenja čijim se korišćenjem dobija distribucija doze prilagođena obliku ciljnog volumena, što omogućava precizno aplikovanje terapijske doze na tumor, uz maskimalnu poštedu okolnih zdravih struktura. Ovaj napredak u kvalitetu radioterapije zasnovan je na napretku kompjuterske tehnologije, primeni savremenih imidžing metoda (CT, MR), konstruisanju pouzdanih radioterapijskih uređaja i kompjuterskih sistema za planiranje zračenja. Glavna razlika u odnosu na konvencionalnu radioterapiju (2DRT) predstavlja korišćenje više zračnih snopova i rezultujuća trodimenzionalna distribucija doze dobijena putem CT simulacije pacijenta.

Pri radioterapiji dece, čiji se organizam nalazi u periodu rasta i razvoja, korišćnje 3D-CRT je od posebnog značaja (4). Na primer, kod dece se mora voditi računa o simetričnom ozračivanju aksijalnog skeleta. U suprotnom, asimetričan rast može dovesti do velikih deformiteta. Kada tretiramo mete koje se nalaze blizu kičme dece, moramo povećati zračna polja kako bi ravnomerno tretirali celo pršljensko telo, da se ne bi prouzrokovao asimetričan zastoj u rastu. Kod dece rast kostiju je zaustavljen ako je data doza veća od 18 Gy. Neke strukture su od ključnog značaja za zaštitu kod dece, dok se u velikoj meri ignorišu u radioterapiji odraslih. Primer je efekat zastoja u rastu dece kada se hipofiza tretira sa više od oko 20 Gy zbog posledičnog smanjenja lučenja hormona rasta. Takođe kod dece, doze na jajnike i testise veće od 5 do 10 Gy mogu prouzrokovati neplodnost deteta, dok odrasli koji su završili svoj reproduktuvni period nisu izloženi riziku od istih doza. Organi koji se mogu oštetiti pri manjim dozama kod dece u odnosu na odrasle, ili su od interesa zbog dužeg vremena tokom koga se toksičnost može manifestovati, uključuju i srce, karotidne i druge arterije, kao i mozak. U palijativne svrhe, 30 do 36 Gy se daje odraslima sa metastazama u mozgu bez većih kognitivnih efekata; međutim, ova doza data trogodišnjem detetu nosi sa sobom poražavajuće posledice.

Dodatno praktično razmatranje pri radioterapiji pedijatrijske poplacije je da je deci mlađoj od 3 ili 5 godina, ponekad i starijoj, potreban tretman u sedaciji ili opštoj anesteziji. Svakodnevna sedacija u trajanju od nekoliko nedelja bezbedno se izvodi čak i kada period sedacije traje do sat vremena ili više. Anesteziolog mora biti prisutan da upravlja procesom i prati bolesnika. Često, kako bi se postigla optimalna ventilacija tokom anestezije, dečija brada mora biti podignuta i zadržana u ovom položaju. Prilikom pravljenja sredstava za imobilizaciju glave, ekstenzija brade se mora uzeti u obzir.

Još jedan važan faktor koji treba uzei u obzir prilikom planiranja zračnog tertmana dece je to da je rizik za pojavu sekundarnih maligniteta izazvanih zračenjem veći kod dece nego kod odraslih. Ovo je možda posledica povećane osetljivosti normalnog tkiva na mutagene efekte zračenja u mlađem uzrastu, veće proliferacije ćelija u ranim stadijumima rasta i razvoja ili genetskih promena povezanih i sa pojavom primarnog maligniteta (5). Dete koje preživi primarni tretman ima mnogo godina pred sobom u kojima može da razvije drugi malignitet.

O svemu navedenom se vodi računa prilikom radioterapijskog tretmana dece u IORS.

Grafikon 1. Distribucija dece prema uzrastu

Grafikon 2. Distribucija dece prema polu
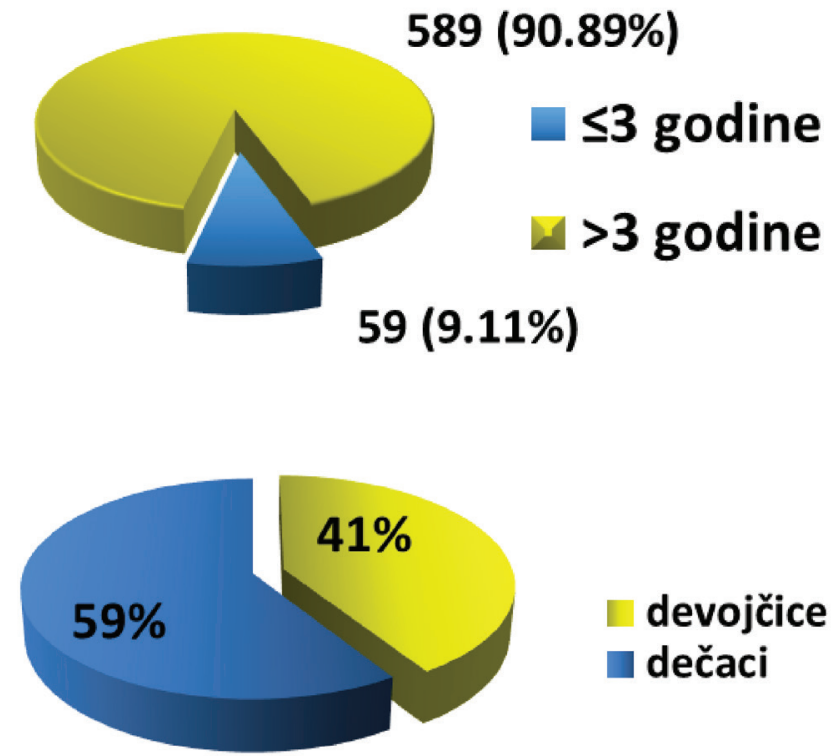

devojčice dečaci

\section{TUMORI CENTRALNOG NERVNOG SISTEMA}

Tumori centralnog nervnog sistema (CNS) čine oko $20 \%$ do $25 \%$ svih maligniteta koje se javljaju u detinjstvu. Moždani tumori su najčešći solidni tumori u pedijatrijskom dobu i posle leukemija čine najčešću grupu maligniteta (6). Za razliku od odraslog doba, u pedija- 
trijskoj populaciji primarni tumori mozga su mnogo češći od metastaza.

Većina moždanih tumora se širi lokalno, u okolno moždano tkivo. Metastaze za moždane tumore uključuju širenje duž neuralne osovine i ekstraneuralne metastaze. Širenje neuralnom osovinom je osobina koju imaju meduloblastomi, ependimomi, tumori germinativnih ćelija i supratentorijalni embrionalni tumori. Oko 30 $40 \%$ meduloblastoma ima diseminaciju prilikom dijagnoze (7). Ependimomi imaju manju tendenciju širenja: $17 \%$ visoko-gradusnih i 3\% nisko-gradusnih (8). Juvenilni pilocitični astrocitom ukoliko je lokalizovan u talamusu ili hipotalamusu može da daje leptomeningealnu diseminaciju. Ekstraneuralne metastaze predstavljaju neuobičajen način širenja tumora mozga koji se nešto češće nalazi kod meduloblastoma i tumora germinativnih ćelija. Najčešća mesta su: kost, kostna srž, pluća, jetra, limfni nodusi. Ovakva diseminacija može da bude i jatrogeno uzrokovana postavljanjem ventrikulo-peritonealnog (VP) šanta.

Većina tumora mozga, sem tumora germinativnih ćelija, prvenstveno se leči primenom hirurgije. Radioterapija je esencijalna komponenta tretmana za mnogu decu sa CNS tumorima. Starost deteta u vreme radioterapije mozga ima značajne reperkusije na razvoj kognitivnih funkcija zbog jonizujućim zračenjem izazvane inhibicije neurogeneze (9). Zbog visokog rizika od neurokognitivne toksičnosti zračenja u veoma mladom uzrastu, radioterapija se u većini slučajeva ne preporučije kod dece mlađe od 3 godine.

Za većinu tumora, definisanje ciljnih volumena najbolje se ostvaruje korišćenjem CT simulacije u koregistraciji sa CT-MR imidžingom. Obično se sprovodi lokalna radioterapija na postoperativno ležište tumora. Jedna od najzahtevnijih tehnika u radioterapiji, koja se vrlo često primenjuje kod dece, je tehnika kraniospinalne zračne terapije. Pri korišćenju ove tehnike cela neuralna osovina treba da bude uključena u ciljni volumen (čitav mozak i kičmena moždina kao i čitav subarahnoidalni prostor). Kraniospinalna radioterapija se klasično sprovodi iz 4 polja: dva opozitna lateralna za pokrivanje kranijuma i po jedno direktno na gornji i donji deo kičme. Pri korišćenju standardnih tehnika, donje granice bočnih polja čitavog mozga su usklađene sa kranijalnom granicom gornjeg kičmenog polja, obično sa pokretnim spojem između polja za kako bi se smanjio rizik od subdoziranja ili predoziranja na kičmenoj moždini. Za kaudalnu granicu polja, treba obratiti posebnu pažnju na završetak tekalne vreće. Položaj je uglavnom pronacioni uz korišćenje termoplastične maske za imobilizaciju. Opseg doza za kraniospinalno zračenje je 23.4-36Gy, a za lokalno zračenje 54-59.8Gy.

Zračenje celokupnog ventrikularnog sistema se najčešće koristi kod pacijenata sa CNS tumorima germinativnih ćelija (10). Zbog toga što je subependimalno širenje tumora često, ciljni volumen uključuje obe bočne, treću i četvrtu moždanu komoru sa adekvatnim marginama. Ako se prilikom zračenja koriste bočna opozitna polja u ovom slučaju očuvanje moždanog parenhima neće biti veliko. Bolja pošteda mozga se može postići korišćenjem konformalnijih tehnika radioterapije.

Nakon primene ovako opsežnih tehnika zračenja, preživeli su u značajnoj meri pod rizikom od razvoja dugoročnih sevela (neurološki deficiti, neurokognitivni i bihejvioralni efekti, endokrina disfunkcija, vaskulopatija i razvoj sekundarnih tumora).

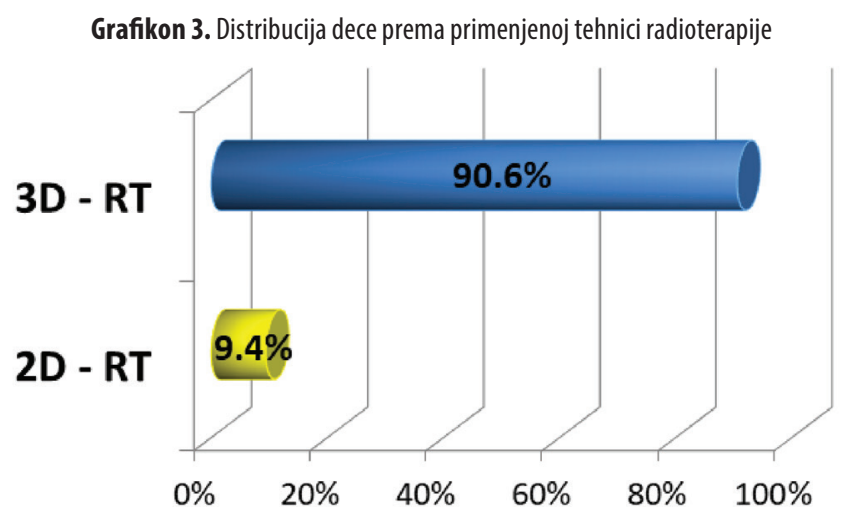

Grafikon 4. Distribucija dece prema primenjenoj tehnici radioterapije u odnosu na različite osnovne dijagnoze

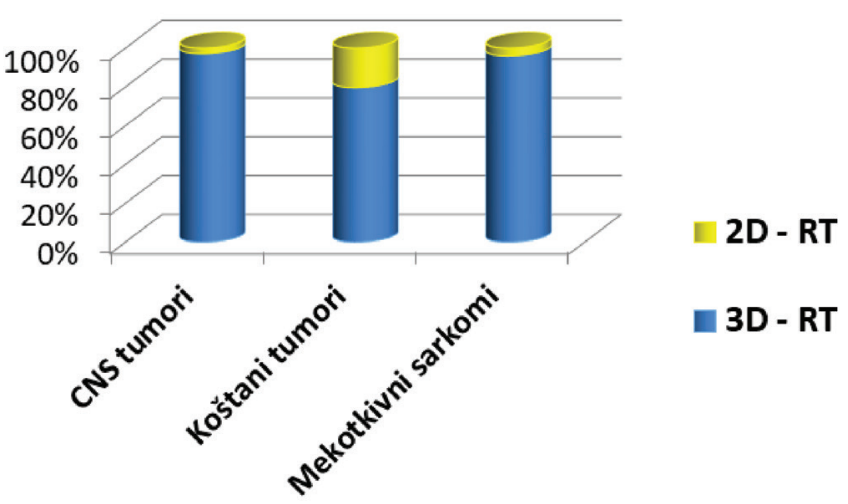

Grafikon 5. Distribucija dece prema različitoj osnovnoj dijagnozi

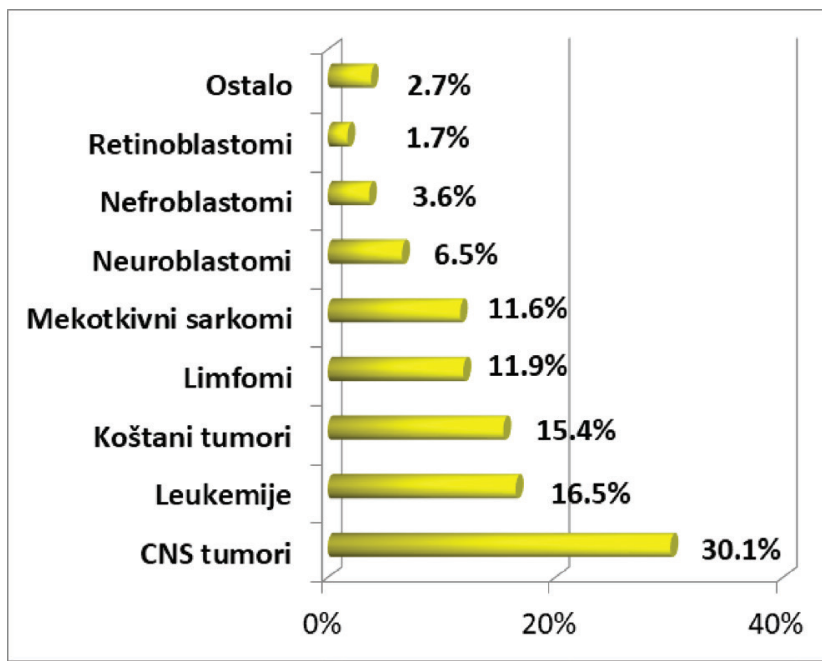


Akutna limfoblastna leukemija (ALL) predstavlja najčešći pedijatrijski malignitet (80\%). U većini slučajeva (oko 90\%) ovi bolesnici imaju dugogodišnje preživljavanje. Pacijenti se klasifikuju u grupe rizika na osnovu broja leukocita u vreme dijagnoze i citogenetskog profila na osnovu čega se određuje terapija.

Osnovni vid lečenja leukemija je hemioterapija. Uloga radioterapije je uglavnom u profilaktičkom ili terapijskom tretmanu kranijuma u kombinaciji sa sistemskom terapijom kod pacijenata sa ALL.

CNS profilaksa se može sprovesti putem iradijacije CNS-a, intratekalnom hemioterapijom i/ili visokodoznom sistemskom hemioterapijom. Cilj je preduprediti CNS bolest ili relaps uništavanjem leukemijskih ćelija na mestima koja nisu lako dostupna sistemskoj hemioterapiji zbog krvno-moždane barijere. Obzirom na značajne kasne sekvele (oštećenje neurokognitivnih funkcija, hipotalamopituitarna disfunkcija, sekundarni maligniteti), kao i na unapređenje sistemske terapije (agensi koji prolaze krvno-moždanu barijeru), kranijalna iradijacija se sve ređe upotrebljava u inicijalnoj terapiji ALL (11). Trenutno se kranijalna iradijacija koristi selektivno kod pacijenata sa visokim rizikom. Spinalni region se tretira intratekalnom hemioterapijom, pre nego radioterapijom.

Kranijalna radioterapija se sprovodi lateralnim opozitnim poljima. U ciljni volumen moraju da budu obuhvaćene kranijalni meningealni omotači koji se kaudalno protežu do C2 ili C3 pršljena. Posebnu pažnju treba obratiti na uključivanje kribriformne ploče, temporalnih lobusa i baze kranijuma u ciljni volumen (12). Kako bi se prevenirali okularni relapsi bolesti, posteriorne $1 / 3$ orbita je potrebno uključiti u ciljni volumen, dok se očna sočiva moraju zaštiti, preporučuje se usperavanje pogleda pacijanta ka stopalima. Pacijenti se zrače u supinacionom položaju sa imobilizacionom termoplastičnom maskom. Najčešći dozni režimi su TD 12 Gy u 8 seansi za profilaktičko zračenje i TD 18 Gy u 12 seansi za terapijsko zračenje kranijuma.

\section{KOŠTANI TUMORI}

Ewing-ov sarkom (ES) je drugi najčešći koštani tumor dečijeg uzrasta, posle osteosarkoma. Etiologija bolesti je nepoznata. ES može da se javi bilo gde u telu. Koštani tumori mogu da imaju intraosealnu i ekstraosealnu komponentu.

Patohistološki ES pripada familiji tumora malih, okruglih, plavih ćelija koje nastaju iz mezenhimalnih stem ćelija. 95\% ima translokaciju između EWS gena na hromozomu 22 i FLI1 gena na hromozomu 11 ili ERG gena na hromozomu 21: t(11:22)(q24:q12) ili t(21:22)(q22:q12).

U ESFT, postoji ekspresija proto-onkogrena c-myc (13).

Najčešća lokalizacija ES su donji ekstremiteti. ES se šire direktnom ekstenzijom primarnog tumora $\mathrm{u}$ okolno meko tkivo i koštane strukture. Oko 25\% ima udaljene metastaze prilikom dijagnoze. One su najčešće hematogene i to u plućima i drugim, udaljenim kostima.Prognoza bolesti zavisi od veličine i lokalizacije primarnog tumora, kao i prisustva udaljenih metastaza. Lošija prognoza aksijalnih lezija je verovatno posledica činjenice da su ovi tumori znatno većih dimenzija prilikom dijagnoze u poređenju sa tumorima ekstremiteta.

Shodno preporukama, lečenje treba otpočeti indukcionom multiagensnom hemioterapijom u toku 6-12 nedelja pre lokalnog tretmana. Nakon indukcione hemioterapije, potrebna je reevaluacija bolesti (kako lokalizovane tako i metastatske). U slučaju povoljnog odgovora (kompletne ili parcijalne remisije), potrebno je sprovesti lokalno lečenje (hirurgija, radioterapija), a potom nastaviti sa hemioterapijom. U slučaju nepovoljnog odgovora, prognoza bolesti je loša i lečenje treba nastaviti lokalnom terapijom ili promeniti režim hemioterapije (14).

Pacijenti koji imaju manje parcijalnog odgovora na indukcionu hemioterapiju (manje od 50\% smanjenja tumorske mekotkivne mase ili loš histološki odgovor na hirurškom preparatu) imaju malu šansu za izlečenje.

Radioterapija se može primeniti pre hirurgije radi smanjenja tumorske mase i postizanja veće šanse za radikalnu resekciju. Mane preoperativne radioterapije su veća učestalost postoperativnih infekcija i otežano zarastanje kosti. Kada se radioterapija primenjuje kao postoperativna omogućen je uvid u patohistološki odgovor tumora na indukcionu hemioterapiju, kao i uvid u resekcione margine. Pri ovom vidu zračne terapije, veći su zračni volumeni jer neophodno obuhvataju kompletan ožiljak. Radikalna/definitivna radioterapija je ranije bila standard. I dalje se primenjuje kao opcija za velike, neresektabilne tumore. Prednosti su što omogućava manje odlaganje hemioterapije zbog nepostojanja zarastanja operativne rane. Nažalost, povezana je sa manjom lokalnom kontrolom u odnosu na kombinovani pristup lokalnog lečenja (15).

U zavisnosti od lokalizacije bolesti, pacijenti se mogu tretirati u supinaciji, pronaciji ili lateralnoj poziciji. Koristi se CT simulacija, ali se preporučuje fuzija sa inicijalnim i posthemioterapijskim MR imidžingom (najbolje demarkiraja ceo tumor uključujući intra- i ekstraosealnu komponentu). Kod tumora koji su uz torakalnu ili peritonealnu duplju, ciljni volumeni se definišu o odnosu na marginu tumora nakon indukcione hemioterapije kada se zdravi odgani vraćaju u normalnu anatomsku lokalizaciju te nema potrebe za zračenjem tih zdravih 
tkiva. Preporučene radioterapijske doze su u opsegu 45$55.8 \mathrm{~Gy}$ uz dozu po frakciji 1.8Gy.

Skelet dece i adolescenata je osetljiv na zračenje i moguće su brojne sekvele: deprivacija rasta dugih kostiju, frakture dugih kostiju, hipoplazija pljosnatih kostiju, skolioza, mišićna hipoplazija, limfedem, indukovani sarkomi. Zbog moguće skolioze, prilikom zračenja pršljenskih tela, pravilo je da celo pršljensko telo mora biti u ciljnom volumenu (16).

\section{MEKOTKIVNI SARKOMI}

Rabdomiosarkom (RMS) je najčešći mekotkivni sarkom dece i adolescenata. Nastaje iz nezrelog poprečno-prugastog mišićnog tkiva i zajedno sa ES, neuroblastomom i limfomom spada u dečije tumore tzv. malih plavih okruglih ćelija. Patohistološki RMS se deli na: embrionalni, alveolarni i pleomorfni tip.

Multiagensna hemioterapija se primenjuje u tretmanu svih pacijenata sa rabdomiosarkomom (17). Hirurško lečenje je važna komponenta lokalnog tretmana RMS. Cilj hirurškog lečenja je kompletna resekcija tumora. U pedijatrijskoj populaciji, primarni cilj je takođe prezervacija organa.
Doze i vreme primene radioterapije zavise od kliničke grupe i lokalizacije bolesti (18). Prema preporukama, svi pacijenti sem kompletno resekovanog embrionalnog RMS se tretiraju radioterapijom. Pacijenti sa mikroskopskom rezidualnom bolešću se tretiraju dozom 41,4 Gy, dnevnom dozom 1,8 Gy. Orbitalni tumori se obično tretiraju dozom od $45 \mathrm{~Gy}$. U regiji glave i vrata, gde najčešće postoji makroskopska rezidualna bolest koju treba tretirati radioterapijom, potrebna je doza od 50,4 Gy.

\section{NeUroblastom}

Neuroblastom (NB) je najčešći ekstrakranijalni solidni tumor kod dece. Skoro $90 \%$ pacijenata je mladja od 5 godina (19). NB može da se javi bilo gde u telu. Najčešća lokalizacija tumora je abdomen, mada često može imati ishodište u paraspinalnom simpatičkom lancu u vratu, grudima i pelvisu.

NB zajedno sa ganglioneuromom i ganglioneuroblastomom pripada neuroblastnoj grupi tumora koji su na različitom stupnju diferencijacije. Neuroblastom pripada familiji tumora malih, okruglih, plavih ćelija i tipično je imunohistohemijski pozitivan na neuronalne markere kao što su sinaptofizin i neuron-specifična enolaza. Patohistološka slika je važan prognostički faktor.

Slika 1. Primer 3D konformalne radioetrapije neuroblastoma sprovedene u IORS

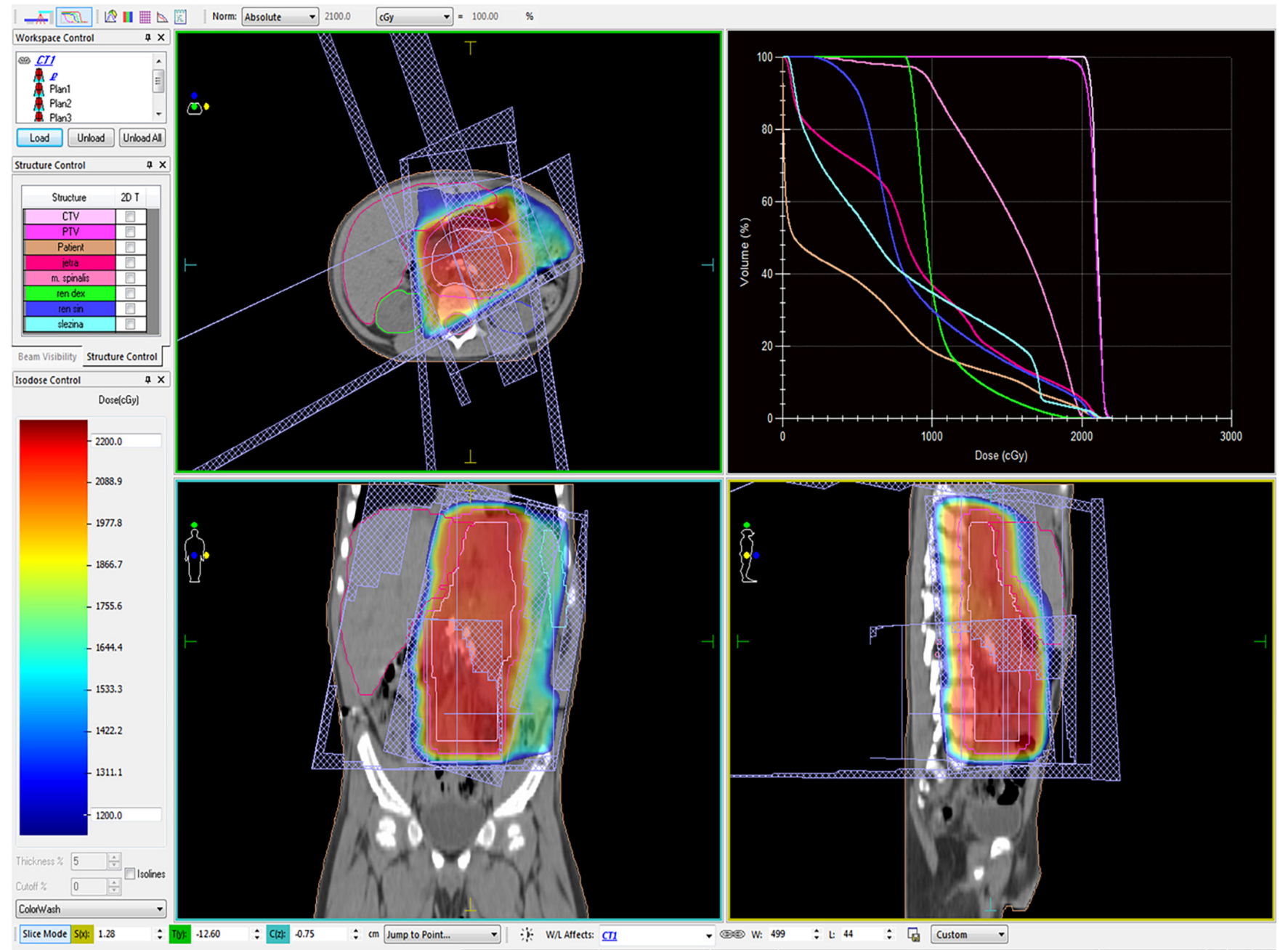


U najvećem broju slučajeva, bolest se manifestuje kao metastatska (20). Što je dete starije životne dobi, tendencija je da bolest bude više diseminovana pri prezentaciji. Bolest može da metastazira limfogeno i hematogeno a najčešća mesta sekundarnih depozita su kostna srž, kost, jetra, limfni čvorovi i koža. Metastaze u mozgu i plućima nisu česte.

Prognostički faktori su: starost deteta, posthirurški stadijum, histološka grupa, DNK ploidija. U jednoj grupi NB onkogen MYCN koji je lociran na 2p24 može da bude amplifikovan, što je snažno povezano sa lošom prognozom.

$\mathrm{Na}$ osnovu navedenih kriterijuma, bolest se prema INRG klasifikacionom sistemu deli na: nisko-, srednjei visoko rizičnu grupu (21).

Tretman NB (hirurgija, hemioterapija, radioterapija) se individualno određuje na osnovu parametara bolesti i pripadnosti određenoj grupu rizika. Zbog tendencije bolesti ka sistemskom širenju, hemioterapija predstavlja osnov terapije. Hirurgija nije indikovana u povoljnoj histološkoj grupi i kliničkoj grupi niskog rizika. U grupi visokog rizika, indikovana je maksimalna bezbedna tumorska resekcija. Radioterapija se više ne preporučuje u nisko i srednje rizičnoj grupi. U grupi visokog rizika, ima značajnu ulogu u multidisciplinarnom lečenju.

Tehnika radioterapije zavisi od lokalizacije tumora. Ciljni volumen za abdominalnu lokalizaciju obuhvata: volumen tumora nakon indukcione HT i regionalne zahvaćene paraaortne limfne noduse. Za većinu pacijenata optimalna je konvencionalna tehnika opozitnim poljima. Ukoliko postoji blizak odnos sa nekom kritičnom strukturom, preporučuje se neka konformalnija tehnika. Ležište primarnog tumora predstavlja najrizičnije mesto za relaps i nakon agresivne hemioterapije. Efikasna doza na ležište primarnog tumora je 20-24Gy. Hirurgija i radioterapija omogućavaju maksimalnu lokalnu kontrolu kod visokorizične grupe pacijenata, i time popravljaju prognozu bolesti (22).

\section{NeFroblastom}

Vilmsov tumor ili nefroblastom, je najčešći abdominalni tumor kod dece i čini 5-6\% svih dečijih kancera.

Najvažniji prognostički faktor za nefroblastom je patohistološki podtip, sa najgorom prognozom kod anaplastičnog oblika a najboljom kod povoljne histologije.

U Severnoj Americi se najpre radi nefrektomija a potom sprovodi hemioterapija i eventualno zračna terapija prema protokolima (23). U Evropi se hemioterapija primenjuje pre nefrektomije. Biopsija renalne mase se ne preporučuje jer oštećenje renalne kapsule znači veći stadijum i potrebu za zračnom terapijom.
Radioterapija abdomena se primenjuje dve nedelje nakon nefrektomije. Kod nefroblastoma povoljne histologije, radioterapija se primenjuje u stadijumu III lokalne bolesti, tj. ako postoje pozitivni limfni nodusi i pozitivna mikroskopska ivica resekcije. Ciljni volumen uključuje primarno ležište (tumora i bubrega) i pridružene paraaortne limfne noduse. U zračno polje treba uključiti pršljenska tela celom širinom kako ne bi došlo do skolioze. Ukoliko je postojala preoperativna ruptura tumora, u slučaju peritonealnih metastaza ili operativnog difuznog rasipanja tumora, potrebna je zračna terapija celog abdomena. U nekim slučajevima plućnim metastaza, primenjuje se i zračna terapija celih pluća.

U stadijumima I-IV fokalnog anaplastičnog tumora i stadijumu I-II difuznog anaplastičnog tumora, RT doze i polja su identični sa nefroblastomom povoljne histologije (24). Stadijum III difuzni anaplastični treba da primi veću dozu.

Zbog odličnog preživljavanja dece sa nefroblastomom, cilj terapije mora da uključi i minimiziranje kasnih neželjenih efekata radioterapije (25). Neke od najčešćih sekvela su: skolioza, kifoza, hipoplazija mekog tkiva, moguće su i renalna disfunkcija, opstrukcija creva, srčana oboljenja, sekundarni maligniteti.

\section{ISKUSTVO IORS U PEDIJATRIJSKOJ RADIOTERAPIJI}

Godišnje se zračnom terapijom u Institutu za onkologiju i radiologiju Srbije leči 60 do 80 pacijenata uzrasta od 1 do 18 godina. Za decu uzrasta do 3 godine, izuzetno retko i stariju, zračna terapija se sprovodi u anesteziji što ističemo kao značajno iskustvo i kvalitet rada naše ustanove.

U desetogodišnjem periodu u našoj ustanovi, od januara 2007. do septembra 2016.godine, radioterapijom je lečeno 648 dece, od kojih 59 uzrasta manjeg od 3 godine (Grafikon 1). Radioterapijskom tretmanu je podvrgnuto nešto više dečaka u odnosu na devojčice (Grafikon 2). Kod najvećeg broja dece, 90.6\%, sprovodena je zračna terapija upotrebom 3D konfomalne tehnike (3D-CRT), a kod malog broja, 9.4\% konvencionalnom radioterapijom (2D-RT) (Grafikon 3). Gotovo sva deca sa tumorima CNS i sarkomima mekih tkiva tretirana su pomoću 3D-CRT, kao i nešto manji procenat pacijenata sa koštanim tumorima i hematološkim malignitetima (Grafikon 4). Najčešći pacijenti bili su deca sa tumorima centralnog nervnog sistema $30.1 \%$, leukemijom $16.5 \%$, koštanim tumorima $15.4 \%$, limfomima $11.9 \%$, mekotkivnim sarkomima $11.6 \%$, neuroblastomom $6.5 \%$, nefroblastomom $3.6 \%$, retinoblastomom $1.7 \%$ i ostalim retkim tumorima (Grafikon 5). Uz operativno lečenje najveći broj dece lečen je hemioterapijom i radioterapijom, $89.8 \%$. Većina dece kod kojih je sprovedena radioterapija lečena je hemioterapijom u našoj ustanovi, $45.8 \%$. Kod malog broja dece sprovedena je radioterapija kao jedini terapijski pristup, $10.2 \%$. 
Upotreba 3D-CRT je u Institutu za onkologiju i radiologiju Srbije tokom godina beležila stalni porast, da bi konačno postala standard pri radioterapjskom tretmanu dece. Zadovoljni smo implementacijom 3D-konformalne radioterapije u našoj ustanovi (Slika1).

\section{ZAKLJUČAK}

U Institutu za onkologiju i radiologiju Srbije, kao centralnoj ustanovi za pedijatrijsku radioterapiju, u potpu- nosti je usvojena 3D-CRT kao standard u lečenju dece i omladine. U proteklom desetogodišnjem periodu stekli smo sopstvena iskustva koja će nam biti od velike koristi prilikom uvođenja naprednijih tehnika koje očekujemo daljom kupovinom uređaja i opreme za radioterapiju.

\section{Napomena}

Rad je usmeno izložen na mini simpozijumu "Savremeni principi pedijatrijske onkologije", na 46. simpoziju$\mathrm{mu}$ Stremljenja i novine u medicini, Medicinski fakultet u Beogradu, 13.12.2017.godine.

\section{LITERATURA}

1. Armstrong GT, Liu Q, Yasui Y, et al. Long-term outcomes among adult survivors of childhood central nervous system malignancies in the Childhood Cancer Survivor Study. J Natl Cancer Inst 2009;101(13):946-958.

2. Guerin, S., C.Guibout, A.Shamsaldin, et al. Concomitant chemo-radiotherapy and local dose of radiation as risk factors for second malignant neoplasms after solid cancer in childhood: A case-control study. International Journal of Cancer 2007;120 (1):96-102.

3. D'Souza, W.D., and I.I.Rosen. Nontumor integral dose variation in conventional radiotherapy treatment planning. Medical Physics 2003;30 (8):2065-71

4. Aoyama, H., D.C.Westerly, T.R.Mackie, et al. Integral radiation dose to normal structures with conformal external beam radiation. International Journal of Radiation Oncology Biology Physics 2006; 64 (3):962-7.

5. Allan, J.M., and L.B.Travis. Mechanisms of therapy-related carcinogenesis. Nature Reviews Cancer 2005;5 (12):943-55.

6. Ward E, DeSantis C, Robbins A, et al. Childhood and adolescent cancer statistics. CA Cancer J Clin. 2014;64:83-103

7. Packer RJ, Gajjar A, Vezina G, et al. Phase III study of craniospinal radiation therapy followed by adjuvant chemotherapy for newly diagnosed average-risk medulloblastoma. J Clin Oncol 2006;24(25):4202-4208.

8. Beltran C, Naik M, Merchant TE. Dosimetric effect of setup motion and target volume margin reduction in pediatric ependymoma. Radiother Oncol 2010;96(2):216-222.

9. Ellenberg, L., Q.Liu, G.Gioia, et al. Neurocognitive status in long-term survivors of childhood CNS malignancies: A report from the Childhood Cancer Survivor Study.Neuropsychology 2009;23 (6):705-17.

10. Khatua, S., G.Dhall, S.O'Neil, et al. Treatment of primary CNS germinomatous germ cell tumors with chemotherapy prior to reduced dose whole ventricular and local boost irradiation.Pediatric Blood and Cancer 2010;55 (1):42-6.

11. Edelstein, K., N.D’Agostino, L.J.Bernstein, et al.Long-term neurocognitive outcomes in young adult survivors of childhood acute lymphoblastic leukemia.Journal of Pediatric Hematology/Oncology 2011;33 (6):450-8.

12. Silber, J.H., J.Radcliffe, V.Peckham, et al. Whole-brain irradiation and decline in intelligence: The influence of dose and age on IQ score. Journal of Clinical Oncology 1992;10 (9):1390-6.
13. Bailly RA, Bosselut R, Zucman J, et al. DNA-binding and transcriptional activation properties of the EWS-FLI-1 fusion protein resulting from the $\mathrm{t}(11 ; 22)$ translocation in Ewing sarcoma. Mol Cell Biol. $1994 ; 14: 3230-3241$.

14. Shamberger RC, LaQuaglia MP, Gebhardt MC, et al. Ewing sarcoma/ primitive neuroectodermal tumor of the chest wall: impact of initial versus delayed resection on tumor margins, survival, and use of radiation therapy. Ann Surg. 2003;238:563-567

15. Donaldson, S.S. Ewing sarcoma: Radiation dose and target volume.Pediatric Blood \& Cancer 2004; 42 (5):471-6.

16. Ginsberg, J.P., P.Goodman, W.Leisenring, et al. Long-term survivors of childhood Ewing sarcoma: Report from the childhood cancer survivor study. Journal of the National Cancer Institute 2010;102 (16):1272-83.

17. Stevens MC, Rey A, Bouvet N, et al. Treatment of nonmetastatic rhabdomyosarcoma in childhood and adolescence: third study of the International Society of Paediatric Oncology-SIOP Malignant Mesenchymal Tumor 89. J Clin Oncol. 2005;23(12):2618-2628.

18. Terezakis $S$, Wharam. Radiotherapy for rhabdomyosarcoma: indications and outcome. Clin Oncol 2013 Jan;25(1):27-35.

19. Woods WG, Gao RN, Shuster JJ, et al. Screening of infants and mortality due to neuroblastoma. N Eng J Med. 2002;346:1041-1046.

20. Mullassery D, Farrelly P, Losty PD. Does aggressive surgical resection improve survival in advanced stage 3 and 4 neuroblastoma? A systematic review and meta-analysis. Pediatr Hematol Oncol. 2014;31:703-716

21. Cohn SL, Pearson AD, London WB, et al. The International Neuroblastoma Risk Group (INRG) classification system: an INRG Task Force report. J Clin Oncol. 2009;27:289-297.

22. Zage PE, Kletzel M, Murray $\mathrm{K}$, et al. Outcomes of the POG 9340/9341/9342 trials for children with high-risk neuroblastoma: a report from the Children's Oncology Group. Pediatr Blood Cancer. 2008;51:747-753

23. Neville HL, Ritchey ML. Wilms' tumor: overview of National Wilms' Tumor Study Group results. Urol Clin North Am. 2000;27:435-442.

24. Dome JS, Cotton CA, Perlman EJ, et al. Treatment of anaplastic histology Wilms tumor: results from the fifth National Wilms Tumor Study. J Clin Oncol. 2006;24:2352-2358

25. Cotton CA, Peterson S, Norkool PA, et al. Early and late mortality after diagnosis of Wilms tumor. J Clin Oncol. 2009;27:1304-1309. 